\title{
LAS REVISTAS
}

\section{Noticias biográficas de Salaverría}

José María Salaverría, el culto escritor y periodista español, ha sido interrogado recientemente por Teófilo Ortega. De las respuestas-escritas-que el autor de Retratos dió a las preguntas del joven escritor, éste hizo un artículo que ha visto la luz en un número reciente de Revista de las Españas. A continuación reproducimos los trozos cardinales de este interesante trabajo.

-Nací en un faro. Así comienza José María Salaverría las cuartillas donde, satisfaciendo mis deseos, me brinda un esquema de su existencia. Nací en un faro. Recordamos y repetimos sus palabras, percibiendo cómo se levanta en su interior, como ágiles palomas, rumorosa bandada de pensamientos. Nos figuramos sus primeros pasos, su niñez, la iniciación de su temperamento allí entre las olas. Un hombre que nace y comienza a hacerse en un faro, se ha de distinguir mucho de quien nace en un medio distinto, seguro, acogedor.
Por su tenacidad; por su erguirse desafiador ante el peligro; por su forzosa afinidad con el aislamiento. (Ibsen nos dijo que sólo res --recordar el iser o no ser, del atormentado Príncipe de Dinamarca-quien se ciñe y no teme a la soledad.) Ojos que se acostumbraron a ver la belleza y lo temible de la vida-que todo encubıe el mar-sin asombro. El sueño interrumpido por el olfateo constante de las olas, arañando las peñas.

José María Salaverría nos escribe, a continuación de fijar el sitio de su nacimiento, que aquello iué como * predestinarle para una vida de marino. No he llegado a serlo, pero he cruzado por doce veces el Atlántico?. El hambre de mar ha persistido en él, indiferente con las ilusiones que como en todo humano, iban cercenando del árbol magnífico de su espíritu los afanes, las contrariedades, los años. Su silueta de caballeroso hidalgo se perfila como en campo propio sobre un fondo de mar, poblado de navíos. Los años vividos en su compañía le han creado una sensibilidad como ninguna otra capaz de descubrir y gozar sus más escondidas seducciones.

La influencia que sobre José María Salaverría ha tenido esa amenazada cuna de luz, es decisiva. Se puede observar en todos sus pasos, ascendentes y firmes, el ritmo que inyectó en ellos el mundo circundante. De aquel lugar recogió la lección de energía y de amplia visión que fácilmente se 
revela al acercarnos a él, al conocer su vida. Quien nació en un faro y acostumbró a sus tieınos ojos de niño a no asustarse por las tempestades del mar, después, en lucha a brazo partido con todas las dificultades que se le presentaban, supo también mirar todo sin miedo, con una fortalecedora confianza. No creo que haya muchos españoles encumbrados que puedan presentar un pasado de luchador tan copioso.

El mismo José María Salaverría será quien nos lo relate. Como Cervantes, atraviesa las más diferentes y contradictorias tareas para llegar - con una perfecta normalización de su vida, que faltó al infortunado autor de <La Galatea - al fruto de un trabajo sereno, trascendental. También como Cervantes, su apetencia de conocer le lleva a labrarse una cultura general de frondoso ramaje y profundas raíces, devorando, más que leyendo, cuanto cae en sus manos. No hay mejor universidad que una buena biblioteca, decía Carlyle, y en esta Universidad, rebosante de enseñanzas, es donde se ha doctorado José María Salaverría. Hasta los papeles que encontraba por la calle leía, dijeron del famoso luchador de Lepanto. Y asimismo José María Salaverría acumula conocimientos, sensaciones, guiado no por la ambición de llegar a la altura social en que hoy se halla, sino por el placer que en la lectura existe. Porque el goce de leer, como el de producir-según él mismo nos lo dirá más adelante es, para el escritor, uno de los que se colocan por encima de otros muchos.

Pero estamos entrando con excesiva frecuencia en ese campo íntimo del escritor que ninguno otro, mejor que él, puede iluminar con su luz. Copiemos lo que él nos dice exactamente, sin supresiones ni añadiduras (que constituirían en nosotros una estúpida irrespetuosidad), trasladándolo en toda su fragante palpitación de confidencia cordial:

- Mi instrucción oficial y reglamentaria es una historia que se acaba muy pronto de contar: la escuela pública de San Sebastián, la Escuela de Artes y Oficios de la misma ciudad, un colegio particular para <corregir > la letra y aprender la Teneduría de Libros, y basta. El resto he tenido que aprendérmelo yo mismo por ahí, a salto de mata y con la avidez arbitraria y libre del autodidacto.

- Pero no guardo resentimiento contra nadie. Mis padres, de santa memoria, hicieron más de lo que podían por mí y mis pobres maestros no tenían la culpa de que yo fuese un soñador, un perezoso, un tímido y un arbitrario. Me costó bastante ganar la primera peseta, porque no me gustaba ninguna de las profesiones que intentaba. Sólo me gustaba escribir versos, fantasear, perder (¿o ganar?) el tiempo. En mi juventud he sido quién sabe cuántas cosas: desde aprendiz de indiano hasta telegrafista; desde torrero hasta auxiliar de maestro de obras; delineante, empleado. Al fin acabé en escritor que trabaja a destajo, a tanto la pieza y con toda libertad, como los buenos proletarios independientes.

- Pero en esto no ha de traslucirse ningún despecho. Soy escritor por propia elección y estoy satisfecho de serlo, convencido de que no hubiera logrado ser otra cosa. La literatura me ha producido grandes amarguras; pero la culpa fué de mi carácter y de mi sensibilidad excesiva. En compensación me concede a veces incomparables complacencias. En mi último viaje a Venezuela, por ejemplo, en el aislamiento y la augusta serenidad del Atlántico, yo me propuse escribir una novelita de corte completamente romántico. Ocurriría la acción en la catedral de Milán, entre las estatuas que maravillosamente pueblan la fachada y la techumbre del Duomo incomparable. Hasta el protagonista sería una estatua de mármol: El Desdeñoso. Pues bien, yo me refugiaba en mi camarote a escribir mi novela corta, después de haber escuchado sobre cubierta la orquesta imponderable del 
oleaje al ser hendido por la valiente proa del buque, y allí distrutaba lo indecible viendo cómo la obra se iba conformando. Después, en Madrid, encima de tanto placer íntimo, todavía me pagaron por la novelita mil pesetas.
‘El placer de crear es la más grande compensación que me ha dado la literatura. Si la literatura sólo fuera creación, yo habría conocido la dicha completa. Desgraciadamente, el oficio de la literatura está lleno de miserias. ? 